\title{
Kindergarten Teacher Students' Experiences of Value Conflicts in Kindergartens as Educational Institutions
}

\author{
Helene Torsteinson
}

Western Norway University of Applied Sciences, Bergen, Norway

Copyright $\bigcirc 2019$ by authors, all rights reserved. Authors agree that this article remains permanently open access under the terms of the Creative Commons Attribution License 4.0 International License

\begin{abstract}
According to the national guidelines for kindergarten teacher education in Norway, university campus-based teaching and practical training in in-service kindergartens are two mutually complementary learning arenas that facilitate student professional learning and development. This paper "gives voice" to first-year students regarding their experiences of practical training in kindergartens. The students' stories focus on conflicts between their own values and those presented during campus-based teaching as they experienced them in inservice kindergartens. This paper discusses how these can be handled at the institution levels of the campus and inservice kindergartens that are responsible for students' professional and personal growth.
\end{abstract}

Keywords Kindergarten, Teacher Education, Value Conflicts, Students' Experiences

\section{Introduction}

Kindergarten teacher education in Norway is professionoriented, research-based, practice-related education at the bachelor's degree level that qualifies students for educational work with children in kindergartens [1]. During their educations, students are introduced to several different areas of knowledge though classes and activities conducted on campus and at in-service kindergartens. The interdisciplinary subjects taught in these two arenas of the academic campus and kindergartens together are supposed to contribute to students' professional formation and personal growth.

Through participation in the institutional practices of the university, students become familiar with, among others, the kindergarten societal mandate, political steering documents, and kindergarten value-based and other relevant theories. Through participation in in-service kindergartens, students experience how these guidelines, theories, and values are implemented in practice and are used in solving so-called real-life challenges. This, however, can sometimes be experienced as challenging. In this article, voice on these issues is given to students and their stories on experiences from in-service kindergartens.

\section{Theoretical anchoring}

Since the empirical material indicates that the students experienced different issues as "right" and "wrong," I decided to embrace them with the category of values. Values are significantly present in the cultural-historical wholeness approach as they are culturally and historically produced, exercised, reproduced, and also challenged by various social institutions [2]. Values can also be understood as social and relational agreements that set goals for how to act, how something should be, and what is perceived as valuable. It is about what we consider as right or wrong, good or bad, and attractive or not in different situations [3].

Values are more or less directly communicated through policy documents and institutional procedures, but also through actions and in encounters among people. Although both campus and in-service kindergartens work within the same legislation, political steering documents, and regulations, each institution creates its distinctive culture, traditions, structures, and the organization of daily activities. This refers to how the documents are read, interpreted, understood, and practiced by the members of the institutions, and how human, physical, and structural conditions frame them.

This paper employs the cultural-historical wholeness approach [2] to contextualized student experiences of value conflicts and strategies that they use to cope with conflicts. The following are highlighted in this approach: the cultural/social level, the institutional level, and the personal level.

\subsection{Socio-cultural level}

The level of culture and society refers to both the laws and formal organization of society, as well as to the norms, values, and traditions developed in society. Norway is a society with a long tradition of welfare and childcenteredness, which are significant aspects of the so-called 
"good Nordic childhood" [4]. While the welfare state represents democracy, egalitarianism, freedom, emancipation, cooperation, and solidarity, childcenteredness seem to extend these principles to the youngest group in society the children. "Democracy ensures that children have a voice, egalitarianism ensures that children's voices have influence, freedom expands their horizons and the sphere of their influence and emancipation gives them room to explore their options" [5: 293].

These values are mirrored in Norwegian steering documents for the sector of early childhood education and care. The Kindergarten Act [6] and the current Framework Plan for Kindergartens: Contents and Tasks [7] articulate the following as core values:

- the child as a subject and childhood as an intrinsic value;

- democracy - understood as children's right to participate in institutional life;

- diversity and mutual respect;

- $\quad$ equity and equality;

- $\quad$ sustainable development;

- $\quad$ life skills and health [7: 7-12].

The core values of the kindergarten are rooted in basic Christian and human rights values [7, 8] These were articulated in the previous Framework plan for kindergartens ${ }^{1}$ as follows: "The kindergarten will convey basic values such as community, care and co-responsibility, and represent an environment that builds on respect for human dignity and the right to be different. Human equality, freedom of mind, charity, forgiveness and solidarity are key social values that will be used as the basis for care, dance, play and learning in kindergarten" [8: 11].

To safeguard the realization of these values through the institutional life of early childhood education settings, a comprehensive kindergarten teacher education program is provided by the state at the bachelor's degree level. The last reform of kindergarten teacher education in Norway was conducted in 2012. It aimed to improve the conditions for qualifying professional teachers who safeguard the realization of children's need for care, play, cultural formation, and participation through implementing cultural values and professional knowledge into practice. Kindergarten teacher education is to be conducted in close collaboration between higher education institutions and the practice field [1]. Moreover, the academic teachers and inservice teachers are considered to be teacher educators, who both mentor students during practical training periods [1].

\footnotetext{
${ }^{1}$ When the reported study took place, the previous version of the National Framework Plan was valid. However, when it comes to the core values of
}

\subsection{Institutional level}

This means that kindergarten teacher education in Norway takes place in two arenas: academic campuses and in-service kindergartens. These two institutions are, however, declaratively anchored in the same values and are described by the National Guidelines for Kindergarten Teacher Education as mutually co-responsible for student professional formation [1]. While the academic campus operates with academic and professional literature and various teaching and learning methods initiated by adults (either teachers or students), the kindergarten gathers together children, kindergarten teachers, and assistants. Assistants, who comprise the largest group of employees in Norwegian kindergartens, are not obliged to have formal educational qualifications.

The requirement for the number of employees in Norwegian kindergartens is a minimum of one employee for every third child under age three and one employee for every sixth child aged 3-6 years. For every seventh child under age three and every fourteenth child aged 3-6 years, the requirement is for at least one educated kindergarten teacher. There is an ongoing discussion on whether this is satisfactory or not. An analysis conducted by the Directorate of Education [9] shows that only half of kindergartens meet the requirements. It is also reported that the quality of kindergartens can vary highly among individual kindergartens [10]. With regard to this, Aasen and Sadownik [11] report that kindergarten teachers are not always capable of transmitting their professional knowledge and competences in their actions with the whole team.

Another characteristic dimension of kindergartens is the action exigency (Norwegian handlingstvang) that occurs in certain situations. This refers to situations in which immediate action is needed, and there is no time for reflection in advance [12]. A high dimension of action exigency can result in practical actions that do not always correspond with the values anchored in political management documents. Time for reflection often occurs in the aftermath, during staff meetings and through the documentation of one's own work. Additionally, Bae [13] and Johansson [14] refer to cultural and institutional discourses and traditions that sometimes make it difficult to accommodate kindergarten core values.

In the other arena of kindergarten teacher educationthe campus - the dimension of action exigency is significantly lower. The space for professional reflection is created through easily accessible literature, teaching hours, study hours, and group projects. After the reform in 2012, teaching subjects were replaced by interdisciplinary areas of knowledge. One of the first areas of knowledge introduced to the students and followed by practical 
training is Child development, play, and learning. It combines the disciplines of pedagogy (16 ECTS credits), physical education (3 ECTS credits), and music (1 ECTS credit). The learning objectives of this area of knowledge include developing in students an understanding of and good orientation in: a) kindergarten steering documents and formal frameworks, objectives and values, especially children's right to participation; b) theories on all-round development; c) theories and current knowledge on playrelated theories; d) theories on children as subjects and children's right to participation.

The practical training that follows the study of this area of knowledge helps students to develop professional competences by establishing and developing good relationships with children and leading them both as individuals and as groups $[15,16]$. During the first year of the studies, the competences to act professionally in relation to individual children and children in groups are the focus. The students perform their practical training in kindergartens that have formal agreements with the university or college and where the in-service teachers who are mentoring the students must have completed a mentoring course ( 30 ECTS credits). The students conducts their practical training either alone or in groups depending on the possibilities at the in-service kindergartens.

The students spend a total of 100 days in in-service kindergartens, 35 of which are in the first year of the course of study ( 15 days during the fall semester and 20 days during the spring semester). In addition to participating in the daily activities of in-service kindergartens, students attend weekly supervision sessions of 1.5 hours. In advance of the supervision sessions, students submit short written reflection notes that are the starting point for the mentoring session. This may be in the form of a question, observation notes, stories from practice, or a combination of these. The session is conducted by the in-service teacher responsible for student practical training.

The story from practice (Norwegian praksisfortelling) is a method of reflecting on one's own practice. The method involves writing a story about an episode the student experienced from the institutional life of a kindergarten, school, or another care and/or educational institution. The focus of the story from practice relates the author's subjective experience of the situation it describes. The stories are often about things that happened that are central, important, and interesting to those who experienced them $[17,18]$. They are written in every-day language and usually follow the chronological order of the actual situation. The story from practice is supposed to involve the listeners/reader and embrace the complexity of everyday life of the education and care institution. It can give the reader insight into the author's feelings, reflections, and values, and thereby invites reflection and discussion on ethically and emotionally challenging issues [17].

The method is used widely in teacher education and kindergartens in Norway as a tool for reflection and professional and educational development [17], and their learning and developmental potential is widely recognized $[17,19,20,21,22,23,24]$. This method allows students to reflect on real-life episodes using theoretical concepts, which develops their professional language and allows them to link practice with theory [25: 132]. These functions are intended to also be supported by mentoring that, according to reform documents, is the collaborative responsibility of academic and in-service teachers. The role of mentoring is especially important when the students experience ethical dilemmas since the resolution of them will affect their professional and personal growth.

\subsection{Personal level}

According to the cultural-historical theoretical approach, individuals respond to institutional demands and expectations by developing various kinds of motives and actions. It is possible that different actions are demanded of the students on campus and during in-service training. This means that first-year students who are being introduced to the values articulated in the steering documents and literature may experience dissonance when engaging with an institution driven not only by values and theories, but also by economics, administration, and the high frequency of sick leaves and one-day substitute teachers, where work is done not only by educated pedagogues, and where sometimes immediate action is required with little or no time for reflection.

This turns students' practical training and education into encounters in which sometimes other sets of values are shown and practiced than those presented during sessions on campus or in situations in which staff have more time to reflect. At the interpersonal and personal levels, values are communicated through both words and actions, which contributes to reflections (or not) and thereby to motives and actions. In this paper, the students' experiences and reflections on their first practice period in in-service kindergartens are analyzed together with the students' strategies for dealing with the value conflicts and differences they experienced.

According to Hedegaard [2], situations in which individuals encounter contradictions in and between different institutions in which they participate may be at both levels that are particularly advantageous as well as limiting for learning and development. If experiences in an institutional context are supposed to be developing, the experience must be related to while also challenging individuals' previous experiences and perspectives of understanding [2]. Conflicts at the level of values can, however, lead to what Hedegaard [2] refers to as developmental crises, which, when unsolved, limit development and learning. 


\section{Methodological Approach}

The study and this article aimed to give voice to students. Thus, the research questions aimed to reconstruct the students' perspective on their first practical training and were as follows: What are kindergarten teacher education students' experiences of value conflicts during their first period of practical training in in-service kindergartens, and how do students deal with their experiences? The multimethod methodological approach applied to answer these questions combined two qualitative methods, namely written narratives and a group interview. The data generated in writing consisted of 38 sets of student notes written by first-year students after their first practical training.

In the written narratives the students were asked to write freely on their experiences of the practical training. The questions below were provided to guide the students' narratives. However, the students were not obliged to follow them. The questions were as follows:

- How would you describe your first practice period?

- What did you learn most about?

- What did you experience as particularly positive /interesting /marvelous, and why?

- What was challenging and why?

- Think back to a situation in practice that affected you in some way. What was it and how did it affect you?

- Is there anything else you want to add?

Writing and turning in the narratives was voluntarily and anonymous. No names were written on the reflection notes. The students were informed about the purpose of the study and the possibility of withdrawing at any time from participating in the research project. The texts were written and turned in in November 2016 during a session in the area of knowledge of Child development, play, and learning. The students were given 45 minutes to work on the notes during the teaching session. They were also allowed to deliver the reflection notes at a later time if they needed more time to work on them outside of the educational setting. None of the students chose this option. Thirty-eight of a total of 47 students delivered reflection notes. The students were given fictitious names for the analysis.

The written reflections were followed up by a group interview conducted in November 2016. This method of inquiry was chosen because it provides insights into the core experiences of a collective character, which means experiences and reflections that grow as a result of a common/collective social experience [26]; however, these are not necessarily experienced together. The intention behind this was to gain insight into the experiences that the students had in common regardless of individual differences among both the students and the in-service kindergartens. Another reason for choosing the group interview was connected to the fact that a focus group interview can be experienced as less threatening to the participants than individual interviews [27]. The focus group interview was conducted as a conversation among students in which they were encouraged to talk among themselves and discuss in the group without focusing much attention on the researcher. The questions prepared for the interview were the same as those posed for the reflection note.

Compared with the reflection notes, during the focus group interview the students were encouraged to describe and explain more of their experiences and reflections. The focus group interview also allowed for exchanges of experiences, meanings, and discussions among the students, which led to illuminate situations and experiences from several perspectives. According to Tjora [27], the interaction among participants in a focus group interview can add interesting aspects and generate more spontaneous answers than many other forms of qualitative data.

Four students, one male and three female, participated in the group interview. The interview lasted for 63 minutes. It was recorded and transcribed and resulted in 17 pages of text for analysis. The students' names were coded with fictitious names in the anonymized transcripts. Neither personal nor sensitive data were asked for or articulated by the students. Participation in the group discussion was voluntary. The participating students were also informed about the aim of the study, about the use of the data, and about the possibility of withdrawing at any time from participating in the discussion or at any other time from the research project. However, none of the participating students withdrew. They all seemed to be very engaged, including emotionally, in the topic. They did not always agree, but they expressed a lot of empathy, recognition, and respect for each other's experiences and reflections.

\subsection{Analysis}

The data was analyzed using qualitative content analysis [28]. This method provides a systematic strategy to analyze open-ended texts that is about systematizing the empirical material by looking at it through a certain category system and then, based on it, developing subcategories. The main categories used in this study was "students' experiences during the first practical training" and "experiences that affected the students most". The analysis generated the following categories:

- episodes in the in-service kindergartens perceived as conflicting with values presented during campus-based teaching; and

- students' strategies for dealing with perceived value conflicts.

Reading the research material through the framework of the first category allowed supplementing it with various stories and examples that were generalized into two subcategories [29] related to: 1a) engaging with children who presented challenging behavior, and 1b) placing 
students in situations and roles in which they were uncomfortable.

In the second category - students' strategies for dealing with conflicting values - the three following subcategories were designated during the analysis:

- 2a. confronting in-service kindergarten teachers directly with value conflicts the students experienced;

- $2 b$. remaining silent about the value conflicts the students experienced; and

- 2c. writing "stories from practice" and using them as the basis for mentoring.

Table 1. Overview of categories developed during qualitative content analysis. Source: own elaboration.

\begin{tabular}{|l|l|}
\hline \multicolumn{2}{|c|}{$\begin{array}{l}\text { Students' experiences during the first practical } \\
\text { training/experiences that affected the students most }\end{array}$} \\
\hline $\begin{array}{l}\text { 1. Episodes in the in-service } \\
\text { Kindergartens perceived as } \\
\text { onflicting with values } \\
\text { presented during campus- } \\
\text { based teaching }\end{array}$ & $\begin{array}{l}\text { 2. Students' strategies for } \\
\text { dealing with perceived value } \\
\text { conflicts }\end{array}$ \\
\hline $\begin{array}{l}\text { 1a. Engaging with children } \\
\text { presenting challenging } \\
\text { behavior }\end{array}$ & $\begin{array}{l}\text { 2a.Confronting in-service } \\
\text { kindergarten teachers directly } \\
\text { with value conflicts the } \\
\text { students experienced }\end{array}$ \\
\hline $\begin{array}{l}\text { 1b. Placing students in } \\
\text { situations in which they } \\
\text { were uncomfortable }\end{array}$ & $\begin{array}{l}\text { 2b. Remaining silent about } \\
\text { value conflicts the students } \\
\text { experienced }\end{array}$ \\
\hline & $\begin{array}{l}\text { 2c. Writing “stories from } \\
\text { practice" and using them as } \\
\text { the basis for mentoring }\end{array}$ \\
\hline
\end{tabular}

Certain distinctions within the subcategories were detected; however, I decided to present them in a more narrative way so that the student voices are better represented.

\section{Results}

In the section below, the categories from the Table 1 are supplemented with excerpts of empirical material of the students' voices and are supported by my comments.

\section{1a. Engaging with children presenting challenging behavior}

The stories presented below refer to situations witnessed by the students. The situations were about staff reacting to children's challenging behavior. The staff's reactions were perceived by the students as wrong and/or in conflict with the core kindergarten values of inclusion, democracy, and participation. The students criticized the way of practicing inclusion that is about "making everybody fit in" instead of providing conditions where diverse children can experience belonging and participation in the community. The students' voices on these episodes were as follows.

I was a bit disappointed with the morning circles held in the kindergarten. If the children did not follow during the morning circle, they were quickly thrown out into the hallway or the big room to sit there alone. I generally thought that the adults had too little patience and did not manage to think outside the box at all when it came to dealing with conflicts with the children. (...) I understand that it is challenging with troubled children, but I think it is important not to problematize them this way (Mia, reflection note).

In the next story, the student witnessed an exclusion situation in which the in-service teacher corrected him/herself.

There was a little boy who was very eager during the gathering. He participated in everything and wanted to answer all of the questions. After a while, the pedagogical leader said that he was going to the hallway, so he did. I just sat there wondering what's up here? She went after him and retrieved him again when the activity was running. They talked for a little while, but she did not follow him. She was not there with him. It did not take long before she fetched him, because she realized he could not be there alone. Then I was relieved. I realized she could make mistakes and get stressed enough to make such a move. But she managed to understand that it was wrong quite soon. Anyway, I felt that she just should have known it (Andy, focus group interview).

In the next example, the student recounts a situation in which a child was taken out of the group during a meal and placed in the library corner. In this situation, the lack of communication with the kindergarten assistant combined with the student not knowing the child led to insecurity.

It was a two-year-old child. It was during breakfast. I didn't seen the whole situation, because I was sitting with the one-year-olds. Suddenly, the door to the two-year-old group opened. A girl and one of the staff came in. The girl was placed in the library corner, and the assistant went back to her group. The two-year-old girl was obviously very angry. That was clear. Then one of the one-year-olds got curious about the situation and went up to the girl. She was still very angry. What I saw was that she pushed him, and he fell down. I hadn't been on this unit long, less than a week, so I felt very insecure since the one-year-old didn't want any help from me, I didn't really know the two-year old girl, and she didn't know me. I felt that it would have been wrong to intervene in the situation without talking to the assistant... who had just come and left this girl without a word. So I was kind of paralyzed, thinking what do I do now? [Karen, focus group discussion].

The continuation of this story in the group discussion 
was as follows:

Andy: But it wasn't a punishment, was it?

Karen: Yeah, it was.

Sonja: The child was removed from a social setting. Andy: What was the setting actually?

Karen: I guess it was like this that the child didn't want to eat breakfast and became uneasy at the table. I don't know. Anyway, she was removed from other children and had to be in the other room alone - as I see it. So the room [library corner - H.T.] was used as a shame corner...[Group discussion-material].

What is crucial in these stories is a dissonance between early childhood education values and the episodes the students experienced in the real life of the kindergarten institution. The students justified this practice by the fact that the children were acting in ways that were disturbing the rest of the group or that they had challenged the staff. At the same time, the students distanced themselves from such practices (punishment), and to a large extent identified themselves with the children in the situations they described. If they did not identify with the child, the students identified the situation as simply problematic from their own perspective ("what do I do now?"). Both the perspective of the child and the perspective of the student lead to disagreement with the practices witnessed; however, neither of them seemed to enable the students to act and intervene in the situation they experienced.

\section{1b. Placing students in situations in which they were uncomfortable}

In the other subcategory of student experiences, their agency was more visible because the situations required obedience not only from the children, but also from themselves. The student's experience of discomfort was, in this case, connected with a role or a task that they could not identify with and which was imposed on them. They either disagreed with the task itself or with the fact that they were chosen to perform it. The tasks and/or roles that were experienced as uncomfortable were connected with correcting children's behavior or a level of care that the students did not feel capable of performing satisfactorily for various reasons.

I didn't like it at all when someone was scolding the children. The staff at the unit described it as "something we have to do" when children do something wrong in the staff's eyes. I don't think it's right to ask a student, who doesn't know the child, to be a negative role model. (...) I remember a situation in which I was told to be particularly strict with one child, as he was disturbing others very much. Since the practice teacher was assessing me in this and observed me, I did not dare to do anything other than what I was told (Anna, reflection note).
Another student talks about her first diaper change followed by a "putting to sleep" routine. The student made it clear that the child and the student were uncomfortable with the student executing the care task. It was seen by the student as a violation of the child's needs that disturbed the student's relationship with this child.

It was my first diaper change. After a few days in the kindergarten, the in-service teacher asked me if there were any of the children that I felt more connected to than the others. I mentioned an 18-month-old boy. She said I could change his diaper and put him to sleep with her standing in the background. He was anxious at the start of the diaper changing. The in-service teacher was there, but she was looking down so the boy didn't have eye-contact with her. She just told the boy that it was going well. The child calmed down and dressing him before putting him to sleep went well. Then I followed the child to the pram, but in the pram house there was the assistant that had been his primary care person since he started in the kindergarten [a person that the child was very attached to - H.T.]. The boy ran to her and hugged her. But she rejected the child with words "Go to Karen! She's going to put you to sleep today," and she pushed him toward me. He was just standing there, and it was obvious that he didn't want me to put him to sleep. The assistant followed him to me and kind of "gave" him to me. I lifted him up into the pram and tried to lay him down, but it was clearly unsuitable for him. I asked her for help then. She came, packed him into the pram and said, "Sleep well!" This was an incredibly uncomfortable situation for me. I felt it was a violation of the child's needs. This episode broke the trust between the child and me, and he needed more distance from me afterwards. It was not until the last week of practical training that he played with me again (Karen, reflection note).

During the focus group interview, the students discussed episodes in which they perceived the children's rights and needs being violated by either the staff or themselves when following "orders." Like the students above, they chose to understand the situation from the perspectives of the children. The first example designates at the phenomenon of intimacy and children's right to intimacy.

I would think it was terrible if someone who I was unfamiliar with suddenly changed my diaper. And only because they are children, it's in a way OK. (...) I think that a diaper change is an extremely intimate situation, very personal for the child [Karen, focus group interview].

In the next excerpts from the interview, the students paid more attention to what was happening with them when they witnessed children's needs being "disregarded".

I felt very into his situation. I was feeling...maybe not compassion, but I felt let down when I saw the child being disregarded. And I tend to look kind of down on people who don't have the same standards [Andy, focus group 
interviews].

One gets very sad seeing a child being treated unfairly. You have a real internal conflict, actually. On the one hand, the first thing you want to do is to stand up and say that's not right! Stop it! On the other hand, you are being assessed during practical training by those who perform these actions. [Sonja, focus group interview].

As expressed in the last quotation, the students experienced being "trapped" between the perception of the mistreatment of children that pushed them to act, and the fact of being under assessment often by those who committed the actions. However, this did not mean that all of the students reacted to the experiences in the same way. The various qualities of their strategies for dealing with the value conflicts they experienced are described below.

\section{Students' strategies for dealing with perceived value conflicts}

In the students' responses it was possible to reconstruct the following qualities of dealing with value conflicts: a) confronting the in-service kindergarten teacher directly with the value conflict they experienced, b) remaining silent about the value conflicts they experienced, c) writing a "story from practice" and using it as the basis for mentoring.

Regarding to the first opinion-confronting the in-service kindergarten teacher-three of the four students participating in the focus group interview found it hard to confront the kindergarten teacher directly with the value conflict, which led to the next opinion-remaining silent - that seemed to be anchored in the students' difficulties connected with confronting in-service teachers. The students' difficulties indicated they were lacking in professional concepts that would allow them to develop convincing arguments for their own standpoints, react within the power relationship to the "expert" in-service teacher, the in-service teachers' ability to deal with criticism, and the context of being under assessment.

I do not think it's easy to confront the kindergarten teacher with these experiences, because they are going to assess us later, and you do not want to get into an unnecessary conflict. So I think it's hard. Also, because you respect them [the in-service teachers - H.T.] since they know more than you do. I look up to them in a way, so I find it hard to tell them what I think is right. Because I feel like there are those who should know what's right then, in a way [Stine, focus group interview].

It's also difficult because we [the students - H.T.] don't always have enough knowledge even to explain why we think something is wrong. (...) I do not "own" these values yet in a way, so it's hard to explain it with little professional knowledge about it. And as it was with my in-service teacher, she didn't always respect my feedback, because I didn't have the right [professional - H.T.] concepts in there. (...) Actually my in-service teacher was not so good at dealing with criticism generally, as she...well, I suppose that she tended to take it very personally, even if I meant something as a question, not as a critical comment [Sonja, focus group interview].

The third opinion of the students' strategies to deal with experienced value conflicts - writing "stories from practice" and using them as the basis for mentoring - contains conversations about the ethical issues with in-service teachers; however, these did not happen immediately after the situations. The experienced value conflict led the students to use the story from practice, which helped them connect their thoughts and arguments and to reflect on what they found challenging and why before the mentoring session. Some students put the ethical issues in the framework of themselves having difficulties with raising critical issues and asking critical questions when under assessment.

This was something I took up with the in-service teacher. That I found it difficult to raise issues or ask critical questions, just because she was assessing me [as an inservice teacher - H.T.]. And that was something she was very glad that I picked up on. I reflected a lot myself before I sent it (the story from practice - H.T) to her and when reading my stories from practice she gained greater insight into my way of reflecting on certain episodes. In the stories from practice that were sent to her, I described the situation that happened and also my reflections on it. I noticed that she had a better understanding of why I was thinking as I did thanks to this [Karen, focus group interview].

To use the story from practice as the basis for mentoring seemed to be an optimal way of dealing with the value conflicts the students experienced. Thus, the students had an opportunity to reflect on their own experiences and present their own perspectives on certain situations. The students also experienced greater understanding and recognition through their own reflections from in-service teachers.

\section{Discussion}

The students' stories referred to value conflicts experienced at the individual and interpersonal levels. Since the reasons for them lay at the institutional level, I will discuss the institutional tools and solutions that could support students in their experiences of value conflicts. The cultural-historical wholeness approach [2] used in this paper permitted me to place the students' experience of value conflicts as experiences with different values emerging from two different institutions: the university and the in-service kindergarten. Although they are parts of the same kindergarten teacher education, their daily logics 
appeared dissimilar in some situations.

The findings of this study show that the experiences that affected the students most were those related to episodes in which the students perceived violations of the core values of the kindergarten that are connected to the Rights of the Child [30]. The students reacted to the violation of the children's right to respect, an inclusive community, care, and being treated as subjects. These findings are supported by Bae [13] and Johansson [14] who argue that cultural and institutional discourses and traditions sometimes make it difficult to see and engage with children as subjects. They claim that the values presented in steering documents and those shown through actions in kindergartens are not always coherent.

At the same time, most of the students felt insecure and/or unable to act professionally in these situations. Most of them also found it hard to confront in-service teachers directly with their experiences and reflections. In this case, institutional tools - the story from practice and mentoring - helped students handle perceived value conflicts. These tools led to students' own reflections and to their development of professional vocabulary connected to the situation they experienced. Moreover, it also provided in-service teachers with insight into students' reasoning and with time to prepare for mentoring sessions. Thus, both parties benefitted from using these institutional tools for communication and discussing ethical issues.

Nevertheless, there were few students who decided to use the institutionally anchored procedures to deal with the experienced value conflicts. I interpreted the absence of the institutional level in the students' stories as an indication of the need for further student preparation before they entered in-service kindergartens. The preparation should embrace: a) a description of the institutional difference between campus and in-service kindergartens and their daily logics; b) discussing ethical issues that may arise during their first period of practical training; and c) equipping students with institutional tools that can be used when various ethical issues arise. Preparing the students for the institutional shift is, however, only one part of what can been done to support the students' professional and personal growth during practical training.

Another aspect refers to close cooperation between the university and in-service teachers in order to establish a common understanding for the necessity of an explorative, dialogical, and collaborative climate during practical training in order to support students' educational development. Such an atmosphere would stimulate the more spontaneous free exchange of thoughts, reflections, and possible doubts. An openness in dialogue between inservice teachers and students would stimulate learning and professional growth, as there is a great learning potential in the students stories from practice regarding experienced value conflicts. The dialogical culture of openness requires, however, a common understanding of professionalization as a phenomenon that is about various forms of both theoretical and practical knowledge [3]. This however, has to be developed and established through closer cooperation among students, academic and in-service institutions, and teachers.

\section{Conclusions}

After the reform in 2012, higher education institutions and in-service kindergartens are seen as equally important in student professional formation. Both academic and inservice teachers are seen as teacher educators. Nevertheless, the institutions' practices are dissimilar in many ways, which could result in students experiencing value conflicts. I conclude that preparing the students for the institutional shift, together with enabling them with the institutional tools of the "story from practice" and mentoring, is necessary to support the students educational development and growth. Establishing a dialogical, explorative, collaborative culture of practical training that includes students and academic and in-service teachers is equally important.

\section{REFERENCES}

[1] Kunnskapsdepartementet. Nasjonale retningslinjer for barnehagelærerutdanningen. Kunnskapsdepartementet, Oslo. 2012.

[2] M. Hedegaard. Strategies for Dealing with Conflicts in Value Positions between Home and School: Influences on Ethnic Minority Students' Development of Motives and Identity. Culture \& Psychology, Vol. 11, No. 2, 187-205, 2005.

[3] E. Johansson, K. Fugelsnes, M. Röthle, B. Tofteland, B. Zachrisen. Verdipedagogikk i barnehagen. Universitetsforlaget, Oslo. 2015.

[4] B. Kristjánsson. The Making of the Nordic Childhood. In: J. Einarsdottir, J. T. Wagner (Eds.), Nordic Childhoods and Early Education: Philosophy, Research, Policy, and Practice in Denmark, Finland, Iceland, Norway, and Sweden. Information, Greenwich, 13-42, 2006.

[5] J. T. Wagner. An outsider's perspective: Childhoods and early education in the Nordic countries. In: J. Einersdottir, J.T. Wagner (Eds.), Nordic Childhoods and Early Education: Philosophy, Research, Policy, and Practice in Denmark, Finland, Iceland, Norway, and Sweden. Information, Greenwich, 289 - 306, 2006.

[6] Kunnskapsdepartementet. Lov om barnehager. Kunnskapsdepartementet, Oslo. 2005.

[7] Kunnskapsdepartementet. Rammeplan for barnehagens innhold og oppgaver. Kunnskapsdepartementet, Oslo. 2017.

[8] Kunnskapsdepartementet. Rammeplan for barnehagens innhold og oppgaver. Kunnskapsdepartementet, Oslo. 2011.

[9] Utdanningsdirektoratet. Bemanningsnorm og skjerpet pedagognorm - hvordan ligger barnehagene. Statistikknotat 
nr. 4, 2018. Online available from: https://www.udir.no/tallog-forskning/finn-forskning/tema/Statistikknotatbemanningsnorm-barnehage/

[10] OECD. Early Childhood Education and Care Policy Review. Norway. 2015. Online available from: https://www.regjeringen.no/contentassets/ee68f4c948b64c $1 \mathrm{fbc} 45$ baa91f $288472 /$ oecd-norway-ececreview_final_web.pdf

[11] A.Sadownik. W. Aasen. Does the New Kindergarten Teacher Education Program in Norway Provide Good Conditions for Professional Kindergarten Teachers? Universal Journal of Educational Research 7(3A): 1-7. 2019. DOI: 10.13189/ujer.2019.071301.

[12] E. L. Dale, E. L. Utdanning med pedagogisk profesjonalitet. Ad Notam Gyldendal, Oslo. 1999.

[13] B. Bae. Å se barn som subjekt - noen konsekvenser for pedagogisk arbeid i barnehage. 2016. Online available from: https://www.regjeringen.no/no/tema/familie-ogbarn/barnehager/artikler/a-se-barn-som-subjekt---noenkonsekvense/id440489/

[14] E. Johansson. Att närma sig barns perspektiv. I Pedagogisk Forskning i Sverige, Vol. 8, No. 1-2. 2003.

[15] Høgskulen på Vestlandet. BLUPRA1 Den pedagogiske relasjon - observasjon, samspill og barns lek og læring. 2016/2017a. Online available from: https://www.hvl.no/studier/studieprogram/emne/BLUPRA 1

[16] Høgskulen på Vestlandet BULL1-HV Barns utvikling, lek og læring 1. 2016/2017. Online available from: https://www.hvl.no/studier/studieprogram/emne/BULL1$\mathrm{HV}$

[17] L. Birkeland. Pedagogiske erobringer - om praksisfortellinger og vurdering i barnehagen. Pedagogisk Forum, Oslo. 1998.

[18] S.I. Mørch. Pædagogiske praksisfortællinger. In: S.I. Mørch (Ed.) Pædagogiske praksisfortællinger, Systime Academic, Viborg, 21-43, 2004.

[19] M. Eilifsen. Praksisfortellingen - mulighet for sammenheng mellom teoretisk og praktisk kunnskap. In: E. E. Ødegaard,
M. S. Økland (Eds), Fortellinger fra praksis. Trøbbel, vendepunkt og stolthet. Fagbokforlaget, Bergen. 2015.

[20] A.T. Fennefoss, K. E.. Jansen, Praksisfortellinger. PÅ veil til innsikt og forståelse. Fagbokforlaget, Bergen. 2004

[21] K. Kvistad, F. Søbstad, F. Kvalitetsarbeid i barnehagen. Cappelen Akademiske Forlag, Oslo. 2005.

[22] H. Sataøen, Åpne, mangfoldige og respektfulle? Visjoner og kjerneverdier i norske og svenske høyere utdanningsinstitusjoner. Högre Utbildning, Vol. 4, No. 2, 95-108, 2014.

[23] H. Torsteinson. Prosjektbasert arbeid - om barns medvirkning og kunstfaglig aktivitet i barnehagen. In: K. Bakke, C. Jenssen, A. B. Sæbø (Eds.) Kunst, kultur og kreativitet. Kunstfaglig arbeid i barnehagen. Fagbokforlaget, Bergen. 2011.

[24] E. E. Ødegaard, M. S. Økland, M. S. Fortellinger fra praksis. Trøbbel, vendepunkt og stolthet. Fagbokforlaget, Bergen. 2015.

[25] Følgegruppa. Frå førskulelærar til barnehagelærar. Den nye barnehagelærarutdanninga - Muligheiter og utfordringar. Rapport nr. 1. Høgskolen i Bergen, Bergen. 2014.

[26] R. Bohnsack. Documentary method and group discussions. In: R. Bohnsack, N. Pfaff, W. Weller (Eds.) Qualitative Analysis and Documentary Method in International Educational Research. Barbara Budrich Publishers, Opladen \& Farmington Hills, 99-124, 2010.

[27] A. Tjora. Kvalitative forskningsmetoder i praksis. Gyldendal Akademisk, Oslo. 2017.

[28] P. Mayring. Qualitative Content Analysis. Forum: Qualitative Social Research, Vol. 1, No.2, Art. 20, 2000.

[29] L. Cohen, L. Manion, K. Morrison. Research methods in education. Routledge, New York. 2017.

[30] De forente nasjoner. De forente Nasjoners konvensjon om barns rettigheter (Barnekonvensjonen). 1989. Online available from: http://www.fn.no/FNinformasjon/Avtaler/Menneskerettigheter/Barnekonvensjo nen-barns-rettigheter. 